\author{
Aleksandra Wójcicka-Wójtowicz \\ Uniwersytet Ekonomiczny w Poznaniu \\ e-mail: aleksandra.wojcicka-wojtowicz@ue.poznan.pl
}

\title{
SIECI NEURONOWE A PODEJŚCIE OPARTE NA RATINGACH WEWNETRZNYCH. STUDIUM PRZYPADKU
}

\section{NEURAL NETWORKS \\ VS. INTERNAL-RATING BASED APPROACH. A CASE STUDY}

DOI: $10.15611 /$ pn.2018.533.24

JEL Classification: C45, C53, G33, G21

Streszczenie: Banki uważane są za instytucje zaufania publicznego. Zaufanie to zostało nadwyrężone przez ostatni kryzys finansowy w 2007 r. W związku ze wzrostem zanotowanych bankructw banki zaczęły przywiązywać większą wagę do oceny ryzyka kredytowego, które w skrajnych przypadkach może doprowadzić do bankructwa banku. Basel III skupia się na potrzebie uściślenia regulacji dotyczących zarządzania ryzykiem i modeli wywodzących się z ratingów wewnętrznych. Jednocześnie coraz większą popularność w klasyfikacji kredytobiorców zyskują sieci neuronowe. Celem artykułu jest przedstawienie zastosowania perceptronu wielowarstwowego ze wsteczną propagacją w klasyfikacji kredytobiorców i porównanie jakości klasyfikacji z modelem ratingów wewnętrznych. Na podstawie przeprowadzonych badań można stwierdzić, że sieci neuronowe ze względu na łatwość adaptacji i możliwość dynamicznego kształtowania zbioru zmiennych wejściowych (input) osiągają lepsze wyniki klasyfikacji kredytobiorców niż mniej elastyczne metody, takie jak testowana metoda IRB.

Słowa kluczowe: ryzyko kredytowe, sieci neuronowe, metoda wewnętrznych ratingów, klasyfikacja kredytobiorców.

Summary: Banks were always considered the institutions of public trust. However, this trust was significantly violated in the past crises. The insufficiency of some approaches led to the implementation of new improved methods such as artificial neural networks (ANN). The classification task in risk management can be of identifying potential debtors due to their ability to pay back the debt in contractual time due to the ex-post financial information. The objective of the paper is to investigate and compare an Internal-Ratings Based method with Multi-layer Perceptron Neural Network in the process of classification of banks' potential clients. The results of those different methods are juxtaposed, and their performance compared to decide whether NN have truly any predictive advantage over other presented methods in forecasting a future default.

Keywords: credit risk, neural networks, IRB method, classification of debtors. 


\section{Wstęp}

Banki uważane są za instytucje zaufania, jednakże zaufanie to zostało mocno nadwyrężone przez ostatni kryzys finansowy, który zapoczątkowała zapaść na rynku pożyczek hipotecznych wysokiego ryzyka (subprime loan) w USA. W związku ze wzrostem zanotowanych bankructw banki zaczęły przywiązywać jeszcze większą wagę do zarządzania ryzykiem kredytowym. Ryzyko kredytowe w banku jest uważane za rodzaj ryzyka bankowego, który może doprowadzić do zaburzenia funkcjonowania banku, a w skrajnych przypadkach nawet do jego bankructwa. Trend globalizacyjny, przenoszenie się kryzysów pomiędzy gospodarkami i międzynarodowe powiązania korporacyjne powodują, że ryzyko kredytowe znajduje się w centrum uwagi banków. Prawidłowa klasyfikacja wiarygodnego i wątpliwego kredytobiorcy jest kluczowa dla banku. Ograniczenie liczby kredytów przyznanych firmom o niskiej wiarygodności kredytowej może znacząco wpłynąć na sytuację banku. Podstawą do stworzenia przez sieć modelu klasyfikacyjnego są dane historyczne zawierające informacje o poprzednich klientach banku wraz z informacją o spłaceniu przez nich lub braku spłaty kredytu [Witkowska 2002], a także o początkowej klasyfikacji klienta do odpowiedniej grupy ratingu kredytowego.

Bazylejski Komitet Nadzoru Bankowego (Basel Committee on Banking Supervision) zwraca uwagę na znaczenie prawidłowego zarządzania ryzykiem. Basel III szczególnie skupia się na potrzebie uściślenia regulacji dotyczących zarządzania ryzykiem i jego nadzoru. Potwierdza także i rozszerza podstawy przedstawione w poprzednim dokumencie (Basel II), odnoszące się do ryzyka kredytowego i modeli wywodzących się z ratingów wewnętrznych (Internal-Based Rating Approach, IRB), które opiera się głównie na metodach wywodzących się z metod scoringowych. Jednakże coraz większa popularność w klasyfikacji potencjalnych dłużników zyskują sieci neuronowe (Neural Networks, NN). Ważnym elementem przy wyborze sieci jest jej struktura i dane wejściowe

Celem artykułu jest przedstawienie możliwości zastosowania NN w klasyfikacji potencjalnych klientów banku i porównanie jakości klasyfikacji z modelem ratingów wewnętrznych opartym na metodzie scoringowej. Mimo że sieci neuronowe są szeroko omawiane w literaturze, ich realne wykorzystanie jest ograniczone. Jedną z przyczyn jest postrzeganie sieci neuronowych jako narzędzia, które mimo uzyskiwania dobrych wyników stanowi pewnego rodzaju ,czarną skrzynkę”, w której nie można prześledzić zachodzących procesów czy jednoznacznie określić dominujących czynników wpływających na ostateczny wynik. W związku z tym podejmowanie tematu stosowania sieci neuronowych jest jak najbardziej pożądane, gdyż formalnie banki mają możliwość stosowania sieci neuronowych w ramach metody ratingów wewnętrznych (IRB). 


\section{Sieci neuronowe oraz system wewnętrznych ratingów w literaturze}

Literatura na temat metod klasyfikacyjnych, takich jak sieci neuronowe, analiza dyskryminacyjna (AD) czy metody scoringowe (MS), jest bardzo szeroka. W przypadku opracowań dotyczących metod opartych na ratingach wewnętrznych możemy dotrzeć głównie do kwestii czysto teoretycznych ze względu na fakt, że metody IRB są wewnętrzną tajemnicą banku.

Idea sztucznych sieci neuronowych została oparta na sposobie funkcjonowania ludzkiego mózgu. NN są uproszczonym modelem biologicznych komórek nerwowych, w których poprzez odpowiednie sygnały dane wejściowe są przetwarzane, by ostatecznie uzyskać informację na wyjściu. W sieciach neuronowych potrzebne do tego są sygnały wejścia, funkcje aktywujące oraz wagi. Do najprostszych funkcji aktywizujących należą funkcje identycznościowe, które w konsekwencji definiują funkcjonowanie tzw. neuronu liniowego [Lula i in. 2007].

W literaturze sieci neuronowe definiowane są np. jako ,zbiór prostych jednostek obliczeniowych, dynamicznie ze sobą powiązanych, przetwarzaących dane, komunikujących się ze sobą, pracujących równolegle, których działania i aktywacja prowadzą do uzyskania wyniku na wyjściu [Witkowska 2002].

Sieci neuronowe ze względu na swoją naturę są metodą dyskryminacyjną i dostarczają informacji na temat oszacowań prawdopodobieństw a posteriori określonych klas [Richard, Lippmann 1991]. Atiya [2001] w swojej pracy prezentuje podejście empiryczne oparte na powiązaniach między upadłością przedsiębiorstwa a jego charakterystycznymi cechami. Wyniki badań wykazują przewagę sieci neuronowych nad innymi modelami i potrzebę ulepszania algorytmów uczenia się sieci, wyboru architektury sieci i doboru danych wejściowych. Baesens i in. [2003] w swojej pracy badali wkład, jaki mogą wnieść sieci neuronowe w zarządzaniu ryzykiem kredytowym, a konkretnie to, na ile sieci neuronowe mogą pomóc w odpowiedzi na pytanie, dlaczego określony klient jest klasyfikowany jako dobry lub zły. Autorzy stwierdzają, że zarówno sieci neuronowe, jaki i drzewa decyzyjne stanowią bardzo efektywne narzędzie pozwalające na skonstruowanie zaawansowanych i przyjaznych użytkownikowi systemów wspierania decyzji związanych z oceną ryzyka kredytowego.

Eksperyment przedstawiony w pracy [Tsai 2000] na pięciu zbiorach danych z ogólnodostępnych źródeł wskazuje, że probabilistyczne sieci neuronowe ze zmiennymi wejściowymi dobranymi ad hoc osiągają lepsze wyniki jakości klasyfikacji wykorzystujących dane wejściowe wybrane metodą benchmarku oraz pochodzące $\mathrm{z}$ analizy dyskryminacyjnej. Podobne wyniki wyższej efektywności sieci neuronowych w odniesieniu do analizy dyskryminacyjnej uzyskano dla danych pochodzących z polskich przedsiębiorstw [Wójcicka-Wójtowicz, Piasecki 2017; Wójcicka-Wójtowicz 2017; 2018]. 
W [Papatla i in. 2002] porównywano różne modele wyboru z sieciami neuronowymi i wykazano, że modele hybrydowe są w stanie wychwycić aspekty o charakterze predykcyjnym, których standardowe modele nie identyfikują.

$\mathrm{W}$ przeprowadzonym badaniu analizowane będą wyniki uzyskiwane przez perceptron wielowarstwowy (MLP).

\section{Metodyka badań}

W badaniu porównano wyniki dwóch metod: a) sieć neuronową - perceptron wielowarstwowy ze wsteczną propagacją (backpropagation) oraz b) stosowaną w praktyce metodę ratingów wewnętrznych.

Dane pochodzą z trzech źródeł: dokumentacji bankowej, Sądu Rejonowego (Wydział Gospodarczy) i serwisu bankier.pl. Dane podzielono na grupę uczącą się (75\%) i testową (25\%). W metodzie IRB dane wejściowe to 6 wskaźników finansowych - patrz tab. 1 . W przypadku NN zastosowano dwie grupy danych wejściowych: a) wskaźniki, takie jak w metodzie IRB, b) wskaźniki wybrane na podstawie analizy wrażliwości sieci neuronowej z ogólnej grupy 22 wskaźników finansowych.

Badanie obejmuje lata 2014-2016. Wielkość próby uwarunkowana jest liczbą podmiotów sklasyfikowanych jako „zły” kredytobiorca, czyli w badanych latach ogłosił bankructwo, został postawiony w stan upadłości lub z innych przyczyn zaprzestał spłacania zobowiązań wobec banku. Takich podmiotów było 694. Przedsiębiorstwa w próbie pochodziły z różnych sektorów gospodarki, a ich dane są zanonimizowane. Do próby przedsiębiorstw „złych” dobrano taką samą liczbę przedsiębiorstw „dobrych”. Przedsiębiorstwa były dobierane pod względem wielkości sumy bilansowej, a także sektora gospodarki. Ostatecznie cała próba składa się z 1388 obiektów.

\subsection{Metoda ratingów wewnętrznych}

Metoda ratingów wewnętrznych, stosowana do podejmowania decyzji kredytowej oraz późniejszego monitorowania indywidualnych kredytobiorców, nosi znamiona metody scoringowej (Scoring Method, SM). Badanych jest 6 wskaźników finansowych przedstawionych $\mathrm{w}$ tab. 1 . Zestaw wskaźników jest stały i niezmienny, niezależnie od sektora, w którym działa przedsiębiorstwo.

Tabela 1. Wskaźniki finansowe przedsiębiorstw stosowane w metodzie IRB

\begin{tabular}{|c|l|}
\hline Lp. & \multicolumn{1}{|c|}{ Nazwa wskaźnika } \\
\hline 1 & wskaźnik płynności bieżącej \\
\hline 2 & szybki wskaźnik płynności bieżącej \\
\hline 3 & dźwignia finansowa \\
\hline 4 & wskaźnik całkowitego zadłużenia \\
\hline 5 & dług/EBITDA \\
\hline 6 & EBITDA/koszty finansowe \\
\hline
\end{tabular}

Źródło: dokumentacja wewnętrzna banku. 
Dla każdego z tych wskaźników bank ustala określone przedziały identyfikujące poszczególne grupy ratingowe. Wartości wskaźników, zawierające się w danym przedziale, są kwalifikowane do określonej grupy ratingowej. Jeśli przynajmniej cztery wskaźniki przynależą do tej samej grupy ratingowej, to przedsiębiorstwo może zostać do niej zakwalifikowane ze znakiem ,-,". Gdy trzy wskaźniki należą do wyższej grupy ratingowej, a pozostałe trzy - do niższej, ostateczną decyzję pozostawia się analitykowi, choć zwykło się kwalifikować podmiot do grupy niższego ratingu, która wiąże się z wyższym kosztem kredytu lub odrzuceniem wniosku. Jeśli wskaźniki są rozrzucone po różnych grupach ratingowych, to decyzję, do której grupy zakwalifikować dany podmiot, podejmuje analityk w sposób ekspercki. W pracy również posługiwano się tymi zasadami. Decyzja analityka jest jedynie rekomendacją. Ostateczną decyzję podejmuje Komitet Kredytowy.

W przypadku metody IRB badanie obejmuje całą próbę (grupa walidacyjna) z podziałem na lata badanego okresu ${ }^{1}$ oraz ogółem. Wynika to z faktu, że w przeciwieństwie do badanej sieci neuronowej metoda IRB nie wymaga uczenia się.

Jakość klasyfikacji zbadano za pomocą błędów klasyfikacji I i II rodzaju (tab. 2), które odpowiednio kwalifikują „,dobrego” kredytobiorcę do grupy „złych” podmiotów (błąd I rodzaju) oraz „złych” do „dobrych” (błąd drugiego rodzaju). Zwykło się przyjmować, że błąd II rodzaju jest poważniejszy, gdyż pociąga za sobą wymierne straty finansowe. Błąd I rodzaju wiąże się z pojęciem utraconych korzyści, które są problematyczne do oszacowania.

Tabela 2. Błędy I i II rodzaju dla testowanej metody IRB (w \%)

\begin{tabular}{|l|c|c|c|c|}
\hline \multicolumn{1}{|c|}{ Błąd } & 2014 & 2015 & 2016 & Ogółem \\
\hline I rodzaju & 9,48 & 7,58 & 9,48 & 8,07 \\
\hline II rodzaju & 10,9 & 10,43 & 8,77 & 9,15 \\
\hline
\end{tabular}

Źródło: obliczenia własne.

Na podstawie wyników stwierdzono, że różnica między błędem I i II rodzaju (w wartości bezwzględnej) jest niewielka (odpowiednio dla badanych lat: 1,14; 2,85 i 0,71 p.p.), a całkowity błąd klasyfikacji (suma błędów) zazwyczaj kształtuje się na poziomie niższym niż $20 \%$. Spadek w poziomie błędu II rodzaju może być uważany za pozytywny trend.

\subsection{Sieci neuronowe - dane wejściowe $\mathrm{z}$ metody IRB}

Wybór sieci MLP jest podyktowany wcześniejszymi badaniami. Zmiennymi wejściowymi (independent variables) dla całego zbioru (75\% próba ucząca się, $25 \%$ testowa) jest sześć zmiennych z metody IRB przedstawionych w tab. 1. Natomiast

${ }^{1}$ W poszczególnych latach próba ,złych” kredytobiorców wynosiła: 2014 r. - 211 podmiotów, $2015-251,2016-232$. 
zmienna wyjściowa (dependent variable) jest definiowana jako „dobry” lub „zły” kredytobiorca. Wyniki tego podejścia (MLP-SM - Multi-Layer Perceptron, podejście oparte na metodzie scoringowej) wraz z funkcją błędu i aktywacji w warstwie ukrytej i na wyjściu przedstawiono w tab. 3.

Tabela 3. Wyniki jakości klasyfikacji modelu MLP-SM dla grupy uczącej się i testowej

\begin{tabular}{|c|c|c|c|c|c|}
\hline Model & $\begin{array}{c}\text { Jakość } \\
\text { klasyfikacji } \\
\text { w grupie uczącej } \\
\text { się (w \%) }\end{array}$ & $\begin{array}{c}\text { Jakość } \\
\text { klasyfikacji } \\
\text { w grupie testowej } \\
(\mathrm{w} \%)\end{array}$ & $\begin{array}{c}\text { Funkcja } \\
\text { błędu }\end{array}$ & $\begin{array}{c}\text { Funkcja } \\
\text { aktywacyjna } \\
\text { w warstwie } \\
\text { ukrytej }\end{array}$ & $\begin{array}{c}\text { Funkcja } \\
\text { aktywacyjna } \\
\text { na wyjściu }\end{array}$ \\
\hline MLP-SM 6-11-1 & 87,67 & 85,01 & entropia & liniowa & wykładnicza \\
\hline MLP-SM 6-12-1 & 85,33 & 84,33 & Gauss & liniowa & Softmax \\
\hline MLP-SM 6-9-1 & 83,10 & 80,97 & Softmax & wykładnicza & Softmax \\
\hline
\end{tabular}

Źródło: obliczenia własne.

W badaniu sieć przedstawiono w następujący sposób: MLP-SM X - liczba zmiennych wejściowych, Y - liczba neuronów w warstwie ukrytej, Z - liczba zmiennych na wyjściu. Wyniki wskazują, że najlepsza jest sieć 6-11-1 - jakość klasyfikacji w grupie uczącej się wynosi $87,67 \%$, natomiast w grupie walidacyjnej $-85,01 \%$, co jest satysfakcjonujące. Średnia jakość klasyfikacji dla trzech najlepszych sieci wynosi $84,21 \%$, natomiast $\mathrm{w}$ grupie walidacyjnej - 83,43\%. Zatem średnia jakość klasyfikacji przedsiębiorstw $\mathrm{w}$ grupie walidacyjnej dla trzech najlepszych sieci jest średnio niższa tylko o $0,77 \%$ niż w grupie uczącej się. Gorsza jakość klasyfikacji w grupie walidacyjnej nie jest zaskakująca i wynika z natury sieci. Pozytywne jest to, że różnica w klasyfikacji pomiędzy oboma zbiorami jest relatywnie nieznaczna.

\subsection{Sieci neuronowe - dane wejściowe wyodrębnione na podstawie analizy wrażliwości}

W przypadku drugiego podejścia do zbioru danych wejściowych w sieciach neuronowych w badaniu wykorzystano 22 wskaźniki finansowe. Następnie iteracyjnie usuwano ze zbioru wskaźniki, które w analizie wrażliwości zostały przez sieć wskazane jako zbędne.

Analiza wrażliwości w data mining oraz modelach statystycznych odnosi się głównie do oceny zawartych w nich ważności czynników predykcyjnych. Analiza ta pozwala na odróżnienie ważnych zmiennych od tych, które niewiele wnoszą do wyniku działania sieci. Analiza wrażliwości wskazuje zmienne, które bez straty jakości sieci mogą być pominięte i zmienne kluczowe, których nigdy nie wolno pomijać (STATISTICA [https://www.statsoft.pl/textbook]). Jest to ważne, gdyż zmienne wejściowe z reguły nie są niezależne, a analiza wrażliwości wykazuje stratę, jaką ponosimy, odrzucając konkretną zmienną. 
Podstawową miarą wrażliwości sieci jest iloraz błędu uzyskanego przy uruchomieniu sieci dla zbioru danych bez jednej zmiennej i błędu uzyskanego z kompletem zmiennych. Im większy błąd po odrzuceniu zmiennej w stosunku do pierwotnego błędu, tym bardziej wrażliwa jest sieć na brak tej zmiennej.

Jeżeli iloraz błędów wynosi 1 lub jest mniejszy, to usunięcie tej zmiennej nie ma wpływu na jakość sieci.

W wyniku zastosowania analizy wrażliwości (w pakiecie SANN) uzyskano ostatecznie zestaw dziewięciu wskaźników zaprezentowanych w tab. 4.

Tabela 4. Wskaźniki finansowe uzyskane na podstawie analizy wrażliwości

\begin{tabular}{|c|l|}
\hline Lp. & \multicolumn{1}{|c|}{ Nazwa wskaźnika } \\
\hline 1 & wskaźnik płynności bieżącej \\
\hline 2 & wskaźnik szybkiej płynności finansowej \\
\hline 3 & dźwignia finansowa \\
\hline 4 & wskaźnik całkowitego zadłużenia \\
\hline 5 & wskaźnik rentowności aktywów \\
\hline 6 & wskaźnik rentowności kapitału własnego \\
\hline 7 & wskaźnik zyskowności sprzedaży \\
\hline 8 & wskaźnik rotacji należności \\
\hline 9 & wskaźnik zadłużenia kapitału własnego \\
\hline
\end{tabular}

Źródło: obliczenia własne.

Eliminację wskaźników zakończono na etapie, w którym analiza wrażliwości nie wskazywała już żadnego wskaźnika, który można było usunąć bez pogarszania wyników sieci. Wyniki dla trzech najlepszych sieci (MLP-SA - Multi-Layer Perceptron, podejście oparte na analizie wrażliwości) przedstawiono w tab. 5.

Tabela 5. Wyniki jakości klasyfikacji modelu MLP-SA dla grupy uczącej się i testowej

\begin{tabular}{|c|c|c|c|c|c|}
\hline Model & $\begin{array}{c}\text { Jakość klasyfikacji } \\
\text { w grupie uczącej } \\
\text { się (w \%) }\end{array}$ & $\begin{array}{c}\text { Jakość } \\
\text { klasyfikacji } \\
\text { wrupie testowej } \\
\text { (w \%) }\end{array}$ & $\begin{array}{c}\text { Funkcja } \\
\text { błędu }\end{array}$ & $\begin{array}{c}\text { Funkcja } \\
\text { aktywacyjna } \\
\text { w warstwie } \\
\text { ukrytej }\end{array}$ & $\begin{array}{c}\text { Funkcja } \\
\text { aktywacyjna } \\
\text { na wyjściu }\end{array}$ \\
\hline MLP-SA 9-14-1 & 90,33 & 87,11 & Softmax & Tahn & wykładnicza \\
\hline MLP-SA 9-16-1 & 86,23 & 83,33 & Softmax & liniowa & wykładnicza \\
\hline MLP-SA 9-13-1 & 85,67 & 82,88 & liniowa & Tahn & Softmax \\
\hline
\end{tabular}

Źródło: obliczenia własne.

Wyniki uzyskane dla sieci, w których zbędne dane wejściowe zostały wyeliminowane na podstawie analizy wrażliwości, są lepsze niż w przypadku danych wejściowych z metody IRB. Może to być związane z faktem, że sieć na podstawie danych w sposób dynamiczny kształtuje dobór zmiennych, natomiast metoda IRB jest 
statyczna w zbiorze zmiennych wejściowych. Dynamizm sieci i jej relatywnie prosta adaptacja do zmieniających się warunków oraz zbioru zmiennych jest ogromną zaletą stosowania tej metody.

\section{Zakończenie}

Podjęcie złej decyzji kredytowej może ostatecznie prowadzić do znaczących strat finansowych, a w skrajnych przypadkach - nawet do bankructwa banku. W związku z tym prawidłowa klasyfikacja potencjalnych kredytobiorców banku jest tak ważną kwestią. Do klasyfikacji podmiotów wykorzystywanych jest wiele metod, takich jak metody eksperckie, metody scoringowe, drzewa decyzyjne, analiza dyskryminacyjna czy sieci neuronowe. Te ostatnie zyskują coraz większą popularność, głównie ze względu na stosunkową łatwość ich stosowania i elastyczność.

W badaniu testowano metodę ratingów wewnętrznych oraz popularną architekturę sieci perceptronu wielowarstwowego $\mathrm{z}$ dwoma różnymi zbiorami danych wejściowych. Pierwszy zbiór wskaźników pochodził z metody IRB, a drugi był dobrany drogą eliminacji przy użyciu analizy wrażliwości.

Bazując na otrzymanych wynikach, można wnioskować, że sieci uzyskują lepsze wyniki jakości klasyfikacji kredytobiorców, jeśli dobór zmiennych następuje w sposób dynamiczny zależny od sieci, a nie wtedy, kiedy narzucone dane wejściowe są stałe i niezmienne.

Testowana metoda IRB również uzyskuje dobre wyniki, jednak gorsze niż sieć neuronowa. Może to wynikać z doboru zmiennych w modelu i faktu, że metoda ta nie jest w pełni jednoznaczna, tzn. nie zawsze wskazuje w sposób jednoznaczny, do której grupy należy danego kredytobiorcę zakwalifikować. W przypadkach niejednoznacznych ostateczna decyzja opiera się na doświadczeniu analityka kredytowego i może być subiektywna.

Dalsze badania powinny iść w dwóch równoległych kierunkach. Pierwszy z nich powinien skupić się na podejściu hybrydowym, tj. połączeniu sieci neuronowych z elementami metody IRB lub innej metody klasyfikacji kredytobiorców. Drugie podejście w zarządzaniu ryzykiem kredytowym powinno charakteryzować się implementacją sieci o innej topologii i architekturze.

\section{Literatura}

Bartos K., 2012, Wykorzystanie sztucznych sieci neuronowych $w$ badaniach zachowań konsumentów, Zeszyty Naukowe Uniwersytetu Szczecińskiego, nr 703, Ekonomiczne Problemy Usług, nr 88/2012. Haykin S., 2011, Neural Networks and Learning Machines, Third Edition, PHI Learning Private Limited, New Dehli.

https://www.statsoft.pl/textbook.

http://www.SciRP.org/journal/jilsa.

Lula P., Paliwoda-Pękosz G., Tadeusiewicz R., 2007, Metody sztucznej inteligencji i ich zastosowania w ekonomii i zarządzaniu, Wydawnictwo Akademii Ekonomicznej w Krakowie, Kraków. 
Richard M., Lippmann R., 1991, Neural network classifiers estimate Bayesian a posteriori probabilities neural computation, vol. 3, no. 4, s. 461-483.

Tsai C.Y., 2000, An iterative feature reduction algorithm for probabilistic neural networks, Omega, 28(5), 513-524.

Witkowska D., 2002, Sztuczne sieci neuronowe i metody statystyczne - wybrane zagadnienia finansowe, C.H. Beck, Warszawa.

Wójcicka-Wójtowicz A., 2017, Neural networks vs discriminant analysis in the assessment of default, Annales Universitatis Mariae Curie-Skłodowska. Sectio H. Oeconomia, 51 (5), s. 339-349. DOI:10.17951/h.2017.51.5.339.

Wójcicka-Wójtowicz A., 2018, Can artificial neural networks detect fraud? A case study, [w:] Szkutnik W., Sączewska-Piotrowska A., Hadaś-Dyduch M., Acedański J. (red.), 9th International Scientific Conference "Analysis of International Relations 2018. Methods and Models of Regional Development. Winter Edition", Conference Proceedings, Wydawnictwo Uniwersytetu Ekonomicznego w Katowicach, Katowice.

Wójcicka-Wójtowicz A., Piasecki K., 2017, Capacity of Neural Networks and Discriminant Analysis in Classifying Potential Debtors, Folia Oeconomica Stetinensia, vol. 17, issue 2. 